\title{
Towards a Syntax-Semantics Interface for Latin
}

\author{
Andrew M. Devine \\ Stanford University \\ amdevine@stanford.edu \\ Laurence D. Stephens \\ University of North Carolina \\ 1steph8694@aol.com
}

Received: May 24, 2017

Accepted: July 17, 2017

\begin{abstract}
Latin is often cited as a typical example of a free word order language. Free word order inevitably complicates the compositional semantics for any theory in which functions are lexically defined to take their arguments in a fixed order. A number of sophisticated logical mechanisms have been suggested over the years to resolve this problem, but none of them is actually compatible with the Latin data. We adjust the syntax to fit the philological evidence and use the resulting structure as the basis for a simple semantics which allows arguments to be entered into the semantic composition in the order in which they are presented by the syntax.
\end{abstract}

Keywords: Latin semantics; Latin syntax; Latin pragmatics; word order

Resum. Cap a una interfície sintaxi-semàntica per al llatí

El llatí se cita sovint com un exemple típic d'una llengua d'ordre lliure de mots. L'ordre lliure de mots inevitablement complica la semàntica composicional per a qualsevol teoria en què les funcions estiguin definides lèxicament per a prendre els seus arguments en un ordre fix. S'han suggerit diversos mecanismes lògics sofisticats al llarg dels anys per resoldre aquest problema, però cap d'ells no és realment compatible amb les dades del llatí. Ajustem la sintaxi per a adaptar-nos a les dades filològiques i utilitzem l'estructura resultant com a base per a una simple semàntica que permeti que els arguments s'introdueixin en la composició semàntica en l'ordre en què els presenta la sintaxi.

Paraules clau: semàntica llatina; sintaxi llatina; pragmàtica llatina; ordre de paraules

\section{Table of Contents}

\section{Introduction 3. An interface for Latin}

2. Semantics for free word order languages

4. Envoi

References 


\section{Introduction}

While a significant amount of work in the generative perspective has been devoted to Latin syntax over the past ten to fifteen years, the issue of how semantic meaning is derived from the syntactic structures proposed therein has received little attention. This relative neglect of semantics is not very helpful to Classicists at large, who have a vested interest in eliciting precise and complete meanings from the texts they are studying. Conversely, the theoretical semantics literature often cites Latin as a typical free word order language, and offers some highly sophisticated logical analyses designed to resolve the semantic issues arising from free word order crosslinguistically. But, for one reason or another, it tends to operate with a lean and strictly surface syntax, largely insensitive to the finegrained information structure that actually drives word order variation: it leaves out of consideration just the data that a philologist or a pragmatically sensitive syntactician would typically take to be, respectively, the end point and the starting point of any analysis. In our view, the semantic problem of how to interpret the arguments in their various syntactic positions is easier to tackle in the context of some sort of syntactic theory as to what those positions are and, assuming a derivation, how and, particularly, why the arguments got there in the first place.

\section{Semantics for free word order languages}

Consider the following examples:

(1) a. Postea maritus eius tyrannum occidit after husband-nom her-gen tyrant-acc killed 'Afterwards her husband killed the tyrant.'

b. Pedanium Secundum servus ipsius interfecit (TacAnn 14.42) Pedanius-acc Secundus-acc slave-nom his-gen killed 'One of his own slaves killed Pedanius Secundus.'

c. Brutus occidit liberos

Brutus-nom killed children-acc

'Brutus killed his children.'

d. Patrem occidit Sex. Roscius. father-acc killed Sex. Roscius-nom

(Pro Rosc Am 39) 'Sex. Roscius killed his father.'

e. Interfecit Opimius Gracchum. killed Opimius-nom Gracchus-acc 'Opimius killed Gracchus.'

f. At occidit Saturninum Rabirius. but killed Saturninus-acc Rabirius-nom 'But, you say, Rabirius killed Saturninus.' 
The sentences all consist of a function (the verb (V), occidit/interfecit) and its two arguments (the subject phrase (S) and the object phrase $(\mathrm{O})$ ). The latter are either a proper name or a definite, so two individuals (except for the subject in Ann 14.42, which is indefinite, since Pedanius had four hundred servants). Each sentence exemplifies one of the six possible orders in which three different items ( $\mathrm{S}$, V, O) can be arranged: SOV (Con 2.5), OSV (Ann14.42), SVO (Quint 5.11), OVS (Pro Rosc 39), VSO (De Orat 2.132), VOS (Pro Rab 31). Using free variables to generalize over the different arguments, we can represent all of these sentences as $V(x, y)$. Obviously the order of the arguments does not relate to the order in which they appear in the (surface) syntax (which would turn the victim into the aggressor in half of the examples, so that Rabirius would get killed by Saturninus rather than vice versa), but reflects the grammatical relations encoded by the inflectional endings. For instance, nominative is interpreted as encoding subject, and subject is represented by first position in the list of arguments in the lexical definition of the verb. So $(x, y)$ represents ordered pairs of arguments, two individuals in the relation ' $x$ kills $y$.' What sort of compositional mechanisms do we need to derive the correct meaning for the sentences, and how does the compositional process relate to the syntax? In predicate logic, the answer to these questions is actually quite simple. The arguments compose as an ordered tuple (in this case a pair) in one fell swoop: the pair of individuals Rabirius $(x)$ and Saturninus $(y)$ is a member of the set of pairs of individuals $\langle x, y\rangle$ in the relation ' $x$ kills $y$.' This would correspond to a flat syntax, a tree with three sister nodes each one of which could host S, O or V. (A binary branching structure would be theoretically possible for the verb-peripheral orders in an associative compositional system, if the arguments were paired into a constituent corresponding to the product type $\langle x, y\rangle$, [SO] and, with permutation, [OS].) If the various linear orders of the words convey differences of pragmatic meaning, they obviously do not do so structurally on the ternary tree analysis, because there is only one structure. Nor can differences of pragmatic meaning be associated with different derivational steps, because there is only one step in the compositional process. All this is less than satisfactory: the default order in Latin is SOV, not OSV; if SOV is privileged, it ought to be structurally different from the other orders. But in a flat ternary branching structure, all the orders have the same structure, namely none. For there to be a structural difference, the trees have to be binary branching rather than ternary. It follows that the arguments are composed one by one, with the object being composed before the subject in the default order. So the semantics for the sentence in the default order is not the uncurried expression $\lambda<x, y>$. Occidit $(x, y)$, but its familiar curried counterpart, in which the order of the lambda operators sets the order of argument composition. Then the verb occido gets a lexically assigned type $<\mathrm{e}$,et $>$ (rather than $<\mathrm{e} \times \mathrm{e}, \mathrm{t}>$ ) and a corresponding lambda expression $\lambda y \lambda x$.Occid$(x, y)$ : Rabirius is a member of the set of killers of Saturninus. Grammatical relations are encoded by the order of the variables in the lexical definition of the verb and, in common practice, additionally by the alphabetic order of the letters representing the variables (although in principle any letters could be used for the variables: $(y, x)$ or $(u, v)$ would do as well). So the order of composition of $(x, y, z)$ where, for instance, $x$ is the subject, $y$ is the object and $z$ a directional locative, is $z, y, x$. 
Functional application is bidirectional: the types of the elements to be composed determine which is the functor and which is the argument, and the argument may be either to the left or to the right of the functor in the syntax: unlike syntax, meaning is not directional. For instance both [VO] and [OV] combine by functional application to give a single result: both occidit Saturninum and Saturninum occidit compose into the meaning $\lambda x$. Occidit $(x$,Saturninum). While this neutralizes some of the word order variability, if we are going to account for all the different word orders, we will still be stuck with some sentences in which the object is closer to the verb than the subject, and others in which the subject is closer to the verb than the object (after resolution of the ambiguous verb medial ones). The meaning of the latter class cannot be derived from a lambda expression which requires the object to be composed first: these sentences would be just uninterpretable. To get the object to compose before the subject you would need some sort of wrapping rule to move the subject out of the way, but that is a questionable technical mechanism which produces the desired result by brute force without explaining why it is needed in the first place.

Categorial grammar has used a variety of strategies for dealing with free word order (Hoffman 1995; Baldridge 2002; Steedman 2007). The vertical slash is used for directional insensitivity, which helps with the syntax, but, as just noted, this is already built into the semantics. Various type-shifting operations are allowed, for instance raising the subject from the type of an individual $<\mathrm{e}>$ to the type of a generalized quantifier $<$ et, $t>$, and then extending the modes of composition by including logically fancy mechanisms like function composition in addition to the basic mechanism of functional application. Take an example like the following:

\section{(2) Didium Veranius excepit (Tac Agr 14.3) \\ Didius-acc Veranius-nom succeeded \\ 'Veranius succeeded Didius.'}

The subject Veranius is raised to type $<$ et,,$>, \lambda P . P($ Veranius $)$, which then composes with the verb of type $<$ e,et $>, \lambda y \lambda x$.Excepit $(x, y)$, by functional composition to give an expression of type $\langle\mathrm{e}, \mathrm{t}\rangle, \lambda y$. Excepit(Veranius, $y)$; the latter can then take direct object Didium of type $<\mathrm{e}>$ to give a truth value. This analysis does capture the correct pragmatic structure: Didium is topicalized given information and the following $[\mathrm{SV}]$ is the comment, so a constituent of pragmatic meaning. Functional composition here is the nonrepresentational analogue of abstraction over a free variable. Typeraising and functional composition are also used for VSO orders like the example in (1e) Interfecit Opimius Gracchum (De Orat 2.132). If Opimius is raised to type $<$ et, $t>$ and Gracchum to type $<<$ e,et $><e, t>>$, then they can be combined by functional composition to produce the type $<<\mathrm{e}, \mathrm{et}>, \mathrm{t}>, \lambda R \cdot R($ Opimius, Gracchum), which takes the verb to give a truth value. This mechanism is also suitable for nonconstituent coordination and left node raising 
(3) Debere enim se ait... alius consulatum, alius owe for him says one-nom consulship-acc another-nom sacerdotium, alius provinciam. priesthood-acc another-nom province-acc

(De Ben 1.5.1)

'For one man says that he is indebted for the consulship, another for the priesthood, another for his province.'

An alternative and simpler solution available in categorial grammar is to make the compositional process sensitive to the order of the words in the syntax (while retaining the information expressed by the grammatical relations and encoded by the inflectional endings). These objectives are achieved just by changing the definition of the lambda operators from an ordered sequence $(\lambda y \lambda x)$ to an unordered set $\lambda\{x, y\}$ (with alphabetic order encoding grammatical relations, so that $x$ is understood to be the subject and $y$ the object). Then the argument positions can be saturated in any order.

Linking Semantics is a family of theories that match argument variables with case or grammatical relation (Beaver \& Condoravdi 2007; Eckardt 2010; Champollion 2015). In socalled Easy Linking semantics the argument variables are indexed with a case label, for instance $x^{N o m}, x^{A c c}$; one could just as well use grammatical relations $\left(x^{S u b j}, x^{O b j}\right)$ or semantic roles $\left(x^{A g t}, x^{P a t}\right)$. The verb enters the derivation with case-indexed free variables rather than unindexed lambda-bound variables. The noun phrases come from the syntax with their own case labels encoded by the inflectional endings; these semantically activate the corresponding case-indexed variable by triggering lambda abstraction. The result is that the arguments are composed in whatever order they become syntactically available. So going back to our Tacitus example (Didium Veranius excepit), the verb excepit would enter the derivation as $\operatorname{Excepit}\left(x^{N o m}, x^{A c c}\right)$. The verb composes first with the syntactically adjacent subject phrase $\left\langle\right.$ Veranius, $\left.{ }^{\text {Nom }}\right\rangle: \lambda x^{\text {Nom }}\left[\operatorname{Excepit}\left(x^{\text {Nom }}, x^{A c c}\right)\right]$ (Veranius). This produces Excepit(Veranius, $x^{\text {Acc }}$ ), which then composes with the object phrase Didium in the same way. Different word orders use different intermediate expressions to end up with the same ultimate truth value. $\lambda x^{A c c}$. Excepit(Veranius, $x^{A c c}$ ), for instance, is semantically, though not grammatically, passive; it expresses the property of being succeeded by Veranius. Other linking systems work with a slightly different reinterpretation of the notion of verbal argument. Each argument ceases to be simply an individual and is now interpreted as a pair consisting of a grammatical relation (or semantic role or case) and an individual variable: $\langle$ Subject, $x\rangle,\langle$ Object, $y>$. The denotation of a transitive verb is no longer a set of ordered pairs of individuals $\{<\mathrm{a}, \mathrm{b}\rangle,<\mathrm{c}, \mathrm{d}\rangle$, etc. $\}$, but a set of sets of two argument-individual pairs taken in any order $\{$ [Subject, a; Object, b], [Subject, c; Object, d], etc.\}. The denotation of a ditransitive verb is no longer a set of ordered triples of individuals but a set of sets of three argument-individual pairs taken in any order. The verb is linked to its arguments by partial functions which pair individuals with their semantic roles. Every set of argument-individual pairs is the result of a different assignment function. The meaning of a verb 
is then defined as a linking structure which is itself a function from assignment functions to truth values. So in our Tacitus example the meaning of excepit is $\lambda f$.Excepit $(f)$, where $f$ is an assignment function. Composition modifies the verb meaning by adding the relevant pair to the role assignment; the order in which arguments are composed depends on the order in which they are presented by the syntax. To prevent a verb from combining with more than one instance of a given argument, when the composition saturates an argument role the assignment function is modified to remove the saturated argument from its domain. For Veranius excepit we have: $\lambda x \lambda f^{\prime}\left[\right.$ Excepit $\left(f^{\prime}+[\right.$ Subject, $\left.\left.x]\right)\right]$, where $f^{\prime}$ is the same assignment as $f$ in the linking structure above, except that it does not have the subject argument in its domain.

The socalled neodavidsonian theory of argument semantics is widely used in one form or another throughout the semantic literature. It might seem particularly suited to free word order. In this theory the order of argument composition is in principle free, because arguments are treated as permutable modifiers. A transitive verb like occido is not a relation between two individuals but a one-place predicate over events: $\lambda e$.Occid-(e), type $<\varepsilon, t>$ (where $\varepsilon$ is the type for events). The participants are introduced not as arguments of the verb but as arguments of a semantic role relation between an event and an individual: $\lambda e$.Occidit $(e) \wedge$ $\operatorname{Agent}(e$, Rabirius $) \wedge$ Patient $(e$, Saturninus), the set of killing events where the agent of the event was Rabirius and the patient of the event was Saturninus. If the conjunction $\wedge$ is taken to be dynamic and noncommutative, then the order of the participant role relations is relevant. But so long as the conjunction retains its normal commutative (symmetric) character, the order in which the modifiers are composed is irrelevant; there is nothing in the formalism itself that would privilege one particular order or make other orders impossible to interpret (or produce the wrong results, so long as the semantic roles are morphologically identified). So the arguments can enter the derivation in whatever order they are offered up by the syntax, and composition proceeds by progressive intersection of sets of events terminating in existential closure.

We have seen three works that apply their theory to Latin specifically. One (Casadio 1990) is in the framework of typelogical categorial grammar; it uses typeraising, functional composition, the Geach rule, and a decurrying rule called "interchange," $(A / B) / C \rightarrow A /(C B)$. Functor categories are defined by sets of features which include all nominal and verbal inflectional information, as well as part of speech, and X-bar level. Although the presentation is purely syntactic, the results can be translated fairly directly into semantic formulae. A second (Kracht 1999) uses a form of linking semantics in a discourse representation theory framework: variables are indexed for case, number and gender, and the indices are treated as temporary names for discourse referents. Computation proceeds via morphologically controlled merger of discourse representation structures. The third (Casadio \& Lambek 2005) uses its types to encode the complete range of information provided by the morphology, as well as paradigm type, subcategorization, and variation in the order of heads and arguments and of arguments relative to each other. Its enriched type system allows the theory to posit only two rules, left and right contraction. 
We have sketched a number of different semantic mechanisms that have been suggested for resolving the problem of free word order. Typeraising and functional composition extend the flexibility of the compositional rules. Apart from these, the typical strategy is (or at least gives the impression of being) to adjust or operate on the lexical definition of the verb, for instance by relaxing the prescribed order in which the argument positions are to be saturated, or by using grammatical relations in a linking structure that lexically defines the verb, or by reinterpreting the arguments of the verb as arguments of thematic role relations. In our opinion these mechanisms are by and large unsuitable for Latin. More generally, when confronted with the problem of free word order, we have three options available to us: (1) Ignore the syntax, (2) Adjust the logic, and (3) Adjust the syntax. The first option has various incarnations. One is to argue that, since the ultimate semantic translation of the sentence is the same irrespective of the order in which the arguments are saturated, the order of lambda conversion is irrelevant. This has nothing to say about word order regularities in Latin or crosslinguistically; the two lambda expressions could reduce to a single semantic meaning while still having two distinct pragmatic meanings reflecting their different information structures. Another idea is to reconstruct all the arguments back into their base positions and use the resulting structure for the semantics, or to treat free word order as postsyntactic (prosodic) or 'phenogrammatic.' These frameworks tend, to varying degrees, to make the semantics independent of the syntax rather than derived from it. The second option, that of adjusting the logic, is the one chosen by the various compositional systems we have just surveyed. Given the fundamental importance of constituency in syntax, it is reasonable to ban the structural rules of permutation and associativity (both of which destroy constituency). But in response to free word order, the ban on these rules can be partially or fully lifted. A lexical entry of the form $\lambda z \lambda y \lambda x . \mathrm{R}(x, y, z)$ is allowed to permute into $\lambda x \lambda y \lambda z / \lambda y \lambda x \lambda z / \lambda z \lambda x \lambda y / \lambda z \lambda y \lambda x / \lambda x \lambda z \lambda y / \lambda y \lambda z \lambda x$.R $(x, y, z)$, more compactly Perm $\mathrm{R}(x, y, z)$, with the case inflections doing the work that would otherwise be done by fixed argument order. Permutation closure of the serial order in the syntax leads to permutation closure of the order of composition in the semantics. In addition to its potential for uncurrying arguments and creating product argument pairs, associativity can reshape constituency, for instance flipping NP[V NP] into [NP V]NP, with a corresponding shift in the order of semantic composition. In this paper we shall explore the third option, leaving the logic the way it is and adjusting the syntax. Here's why we chose this option. Free word order in Latin is used to express pragmatic meaning: it is not clear why one would want to adjust or reinterpret semantic (lexical) meaning in order to account for pragmatic meaning. For instance, you wouldn't want a separate lexical definition for a verb with a topicalized or scrambled direct object: these are syntactic processes designed to encode pragmatic meaning by adding structure. In fact, while Latin word order is free in a grammatical (semantic) perspective, it is quite stable in a pragmatic perspective; in that sense there really isn't a free word order problem at all, although there is room for disagreement about the details of the structures involved and the contribution of prosody. Rather what 
we need to do is to find compositional mechanisms to express the various pragmatic meanings. The same issue presents itself in a parallel way in the syntax, where we distinguish between a downstairs layer which is lexically oriented (VP), and two upstairs layers, one referentially oriented (IP or TP), and one operator oriented (CP). The arguments of the Latin verb live upstairs, and they should be semantically interpreted where we encounter them in the surface syntax; there is no reason to think that they are reconstructed back into the verb phrase for semantic interpretation. Adjusting the lexical meaning of the verb looks like a downstairs solution to an upstairs problem. (Even a syntactic theory that works with free order base generation (Fanselow 2003) assumes movement to higher positions at LF). Finally, Latin does not have free word order in all sentences: sentences with broad scope focus have a regular default fixed order (which we will analyze in the next section of this paper). If the compositional order is intrinsically free, as it is in the systems we have just reviewed, where does the default fixed word order come from? It looks like those systems have solved one problem by creating another.

\section{An interface for Latin}

Let's start by rehearsing a few well-established facts about Latin syntax. (For further discussion and exemplification the reader is referred to our earlier work (2006)). We will use the term 'broad scope focus' for sentences in which the scope of focus extends either over the whole sentence or over the verb phrase, so sentences that answer the question 'What happened?' or the question 'What did he do?'. Such sentences typically have a fixed (verb final) default word order: subject before direct object before indirect object before directional argument

(4) a. Philotes... hypothecas Cluvio dedit.

Philotes-nom loan-acc Cluvius-dat gave

'Philotes gave Cluvius a loan.'

b. Porcia lex libertatem civium lictori eripuit. Porcia-nom law-nom liberty-acc citizens-gen lictor-dat snatched 'The Lex Porcia rescued our civil rights from the lictor.'

(Pro Rab Perd 12)

c. Hieronymus legatos Carthaginem misit. Hieronymus-nom envoys-acc Carthage-acc sent 'Hieronymus sent ambassadors to Carthage.'

d. Caralitani... Cottam ex oppido eiciunt. Caralitani-nom Cotta-acc out-of town-abl drive 'The people of Cagliari drove Cotta out of the town.'

(Ad Fam 13.56.2) 
mentioned incidentally. Latin is a scrambling language, not in the vague sense of having free word order but in the narrow sense in which languages like German and Turkish are scrambling languages. (Without this insight it is hardly possible to represent Latin syntax in meaningful structural terms at all). Scrambling is not stylistic shuffling but driven by information structure: it typically (but not exclusively) moves unfocused phrases to the left of the focus constituent: the process likes to target specific and definite referential phrases that are given or accommodated information

(5) a. quae Hannibali Locros tradiderat which-nom Hannibal-dat Locri-acc had-surrendered 'Which had surrendered Locri to Hannibal.'

b. legato tuo viaticum eripuerunt legate-dat your-dat money-acc robbed

'They have robbed your legate of his journey money.'

c. Illi ad Caesarem legatos mittunt. they-nom to Caesar-acc envoys-acc send 'They send envoys to Caesar.'

d. Provinciae Q. Cassium praeficit. province-dat Q. Cassius-acc appoints (Ad Fam 12.3.2) 'He put Q. Cassius in charge of the province.'

In these examples the focus is the [OV] constituent, but in others the focus can be narrowly on the preverbal noun phrase. The correlation of scrambling with patterns of informational structure is easily discernible on any page of Latin text; there is some noise in the philological data due mainly to the variable scope of focus and to secondary focus effects, but that is no reason to deny the correlation or to treat scrambling as purely prosodic.

You might think that the obvious structure to posit for the default order in broad scope focus sentences is some sort of simple left-branching tree, and this seems to be implicit in many of the semantic theories reviewed above. But this type of system breaks down spectacularly when we move from the simple three-word subject-object-verb examples in (1) to examples containing adverbial adjunct phrases

(6) a. magnam multitudinem hostium in castris interfecerunt.

large-acc crowd-acc enemy-gen in camp-abl killed

(BAlex 31) 'They killed a large number of the enemy in their camp.'

b. matrem Agricolae in praediis suis interfecit (Tac Agr 7) mother-acc Agricola-gen in estate-abl her-abl killed 'They murdered Agricola's mother on her own estate.' 
Adjunct phrases are very common in preverbal position:

(7) a. postemque tremebunda manu tetigit. post-acc-and trembling-abl hand-abl touched 'And he touched the doorpost with trembling hand.'

(De Dom 134)

b. caput sinistra manu perfricans head-acc left-abl hand-abl scratching 'Scratching his head with his left hand.'

c. Fundum Cymaeum Romae mercatus est. farm-acc Cymaean-acc Rome-loc bought. 'At Rome he bought a property at Cyme.'

d. sescentos milites obscura nocte misit. 600 -acc soldiers-acc dark-abl night-abl sent 'He sent six hundred soldiers in the dark of night.'

These examples illustrate instrumental (De Dom 134, In Pis 61), locative (Pro Flacc 46) and temporal (Frontin 3.9) adjuncts in this position. If we compose the arguments and adjuncts with the verb from right to left in the mirror image of the English order, the adverbials will compose with the verb before the direct objects. But this gives the wrong semantic result. There are familiar scripted events like night-walking, even transitives like oven-baking, but touching with a trembling hand, left-hand-rubbing, Rome-buying and late-night-sending are not among them. 'At Rome' for instance does not modify the verbal action of buying. Rather it tells us where the event of buying the farm took place. 'At the dead of night' does not modify the verbal action of sending but tells us when the event of sending six hundred soldiers took place. The adjunct is not a function from a verb to a verb, but a function from a verb phrase to a verb phrase. Why would the syntax systematically present the expressions in the order OAdjV if the semantics needs to consume them in the order AdjOV? It should be clear by now that a left-branching structure is just too simple. It is the homomorphism between syntactic structure and semantic meaning that makes compositional semantics possible and desirable in the first place: when the homomorphism seems to break down, that can be an indication of some analytical inadequacy. Since the adverbials in (7) have semantic scope over the verb phrase, they should be syntactically located at the left edge of the verb phrase. From the perspective of a theory of syntax that uses movement, the verb's arguments originate in the event description (for instance as specifiers of subevent projections associated with their semantic roles), but they have been evacuated to a higher position in the structure, and we need a formal mechanism that will allow them to be interpreted in their respective higher positions rather than one that will allow them to be interpreted in the wrong order in their lower positions.

As we have just seen, Tacitus tells us that Agricola's mother, Julia Procilla, was killed by Otho's sailors on her estate at Ventimiglia; he also recounts how Julius Mansuetus was killed by his son near Cremona 
a. matrem Agricolae in praediis suis interfecit. (Tac Agr 7) mother-acc Agricola-gen in estate-abl her-abl killed 'They murdered Agricola's mother on her own estate.'

b. filius patrem interfecit.

(Tac Hist 3.25) son-nom father-acc killed

'A son killed his father.'

There is no reason to believe that the direct object patrem in the second example is not in the same position as the direct object matrem in the first example. Since matrem is outside the verb phrase in the first example (because it stands to the left of the locative verb phrase modifier), patrem must be outside the verb phrase in the second example too. It follows that patrem cannot be the sister of the verb interfecit in the syntax and cannot compose with the verb semantically like a complement via leftward functional application. Not only that, but we also have a (nonquantificational) scope problem: the direct object is outside the scope of an adverbial modifier in the surface syntax but, as we just observed, needs to be inside the scope of the adverbial for semantic interpretation of the event. So let us look first at a class of direct objects that transparently present us with just this scopal problem, namely simple topic objects. We use the term simple topics to distinguish them from contrastive topics; simple topics are often called "aboutness" topics. Simple topics can be used to introduce a new topic into the discourse

a. C. Flaminium Caelius religione relicta cecidisse

C. Flaminius-acc Caelius-nom religion-abl abandoned-abl fell apud Trasumenum scribit.

at Trasimene writes

(ND 2.8)

'Caelius writes that C. Flaminius ignored religion and fell at Trasimene.'

b. Ap. Claudium virginis plebeiae stuprandae libido cepit. Ap. Claudius-acc girl-gen plebeian-gen violating-gen desire-nom took (Livy 3.44.2)

'The desire to violate a plebeian girl overcame Ap. Claudius.'

c. P. Cornelium Cn. filium Scipionem et M'. Acilium

P. Cornelius-acc Cn.-gen son-acc Scipio-acc and M'.Acilius-acc

Glabrionem... patres... res divinas facere iusserunt.

Glabrio-acc senators-nom things-acc divine-acc do ordered (Livy 36.1.1)

'The senate ordered P. Cornelius Scipio son of Cn. and M'. Acilius Glabrio to perform sacrifices.'

In these examples the direct object has been raised to the left of the subject. Simple topics can also be used to reactivate (or refresh) an already introduced discourse referent; this is often called a "continuing" topic 
(10) a. Lucretium... C. Lucretium ... tribuni ad populum accusarunt. Lucretius-acc C. Lucretius-acc tribunes-nom to people-acc accused 'Lucretius...the tribunes accused C. Lucretius before the people.' (Livy 43.8.1/9)

b. Didius Gallus... Didium Veranius excepit

Didius-nom Gallus-nom Didius-acc Veranius-nom succeeded

'Didius Gallus... Veranius succeeded Didius.'

(Tac Agr 14.3)

While these objects are clearly part of the predicate, they appear in the surface syntax to the left of the subject, so outside the predicate. The way this problem is solved is illustrated in Figure 1. Topicalized phrases are in the specifier position of a topic phrase projection in the CP layer of the tree, as they are in cartographic syntax. This position is linked to a gap (or a trace or copy) inside the verb phrase. The topic phrase has an empty functional head, the syntactic instantiation of the semantic topic operator that serves to enter the argument into the compositional meaning of the sentence. Its complement is the rest of the sentence, to which we have given the traditional label 'IP.' Semantically, IP has the type $<t>$, because the position of the missing object is filled by a free variable $y ; y$ is like a prodropped argument without the anaphoric link. Temporary saturation of an argument position with a free variable is commonly used as a technical device to handle argument permutation in topicalization, relativization, quantifier scoping, and sometimes also for passivization and subject externalization. In their traceless incarnation, free variables are the basic mechanism in Easy Linking semantics. In natural-deduction based systems of categorial grammar, assumptions are translated as free variables; permutation can be achieved by varying the order of abstraction over the free variables. The functional head Top ${ }^{\circ}$ hosts a typeshifting operator called ABSTR which abstracts on the variable identified by the case ending and thereby shifts an open formula into a predicate. This sort of abstraction is standardly used for the semantics of relative clauses. We can think of the inflectional ending -um as decomposing

Figure 1. Topic Phrase. Didium Veranius excepit (Tac Agr 14.3)

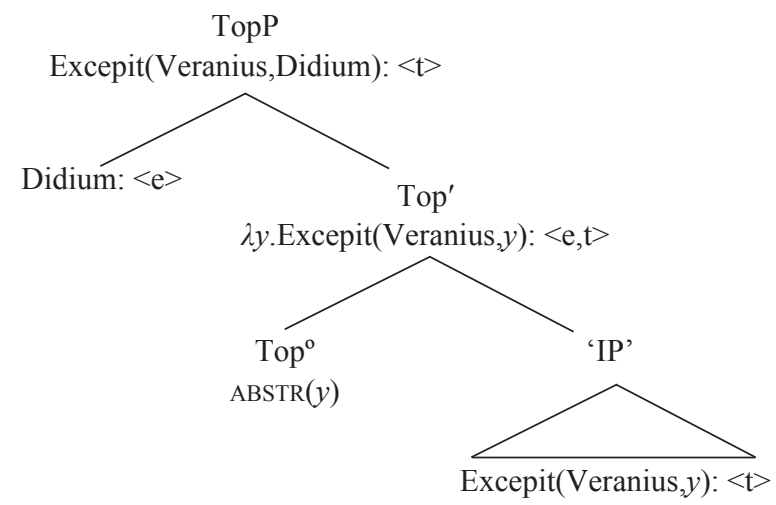


and moving postsyntactically from the specifier to the head to control the choice of the abstracted variable: the variable is restricted to the argument in the appropriate subevent of the event structure. The functional head creates an additional predication superordinate to the basic subject-predicate structure, so that the rest of the sentence (the comment) is predicated of the topic. So the simple topic operator (syntactically, the topic functional head) is a superpredicator, and the topic itself (the specifier of the topic projection) is a supersubject.

The resulting property $\lambda y$.Excepit(Veranius, $y$ ) is then predicated of the topic Didium: Didius $(y)$ is such that Veranius $(x)$ is such that $x$ succeeded $y$. Since $y$ is semantically active in two positions, its base position inside the verb phrase and its higher position outside the verb phrase, the scopal problem is resolved (in the same way as it is for topicalization over quantifiers in sentences like 'In his camp the scouts reported that every general had two legions'). In the system we are using, free variables saturate the argument ('trace') positions in the syntactically evacuated verb phrase in the lexically prescribed order: there is no permutation. This step can be eliminated by using free variables in place of lambda-bound variables in the lexical definition of predicates, as some theories do; but it is useful to be able to distinguish verb-phrase internal from verb-phrase external arguments.

Now we are in a position to return to the problem of the semantic composition of arguments as they appear in the default order in broad scope focus sentences, which is the main concern of our analysis. Take the example in (4d), Caralitani... Cottam ex oppido eiciunt (BC 1.30), which means roughly '[The people of Cagliari CAUSE] [Cotta GO-TO] [Cotta BE-OUT-OF the town]' (Jackendoff 1990; Ramchand 2008). The upstairs default argument order is not semantically random: it replicates the downstairs order of the subeventual decomposition (just as multiple interrogative extractions do). The morphological case inflections lexicalize the grammatical relations, and the latter in turn are linked to the thematic information in the subevent metapredicates. If you change the order of the subevents, you get nonsense. We'll start with the subject. Subjects are traditionally placed in a specifier position, usually one associated with a tense projection, but some theories unhitch tense from predication and posit a separate subject phrase or a phrase whose head is the main predicator of the sentence (PredP). In any case, if there is a specifier, there must be a related head, so the semantics just posited for topics will apply to subjects as well. This makes sense: while it is quite possible for subjects to be focused, prototypical subjects are grammaticalized topics, the phrase of which the rest of the sentence is predicated
C. Servilius Ahala Sp. Maelium... manu sua
C. Servilius-nom Ahala-nom Sp. Maelius-acc hand-abl his-abl occidit. (Cat 1.3)
killed
'C. Servilius Ahala killed Sp. Maelius with his own hand.'
b. Milo Clodium occidit. (Quint 3.5.10)
Milo-nom Clodius-acc killed
'Milo killed Clodius.'


The property of killing Sp. Maelius with his own hand is predicated of Servilius Ahala. The head of the subject phrase again hosts the abstraction operator, with the nominative case inflection triggering abstraction on the subject variable. Now consider again the direct object Sp. Maelium. It is to the left of the adjunct instrumental phrase manu sua, so almost certainly outside the verb phrase. It seems that just as we can have a level of predication superordinate to the subject predication, so we can have one subordinate to it. If topics are super-subjects, direct objects will be sub-subjects, and we can extend our functional head semantics to objects too, also when they are adjacent to the verb as in the second example (Quint 3.5), and to indirect objects if there is one
a. pecuniam Staieno dedit. money-acc Staienus-dat gave 'He gave the money to Staienus.'
b. arma Satricanis ademit. (Livy 9.16.10) arms-acc Satricans-dat took 'He deprived the people of Satricum of their arms.'

Indirect objects are to the right of direct objects in the default order. More generally, most arguments in Latin are placed in the specifier position of a functional head superordinate to the verb phrase; compare the higher object positions posited in object agreement projections, EPP for objects and the VP external object hypothesis (Lasnik 2001; Basilico 1998; Bowers 2010). This applies to arguments in the default order and probably to scrambled arguments too (which account for much, but by no means all, of the socalled free word order in Latin). So the arguments of the verb in a neutral order sentence are not complements in a verb-headed structure, nor are they specifiers in a decompositional subeventual structure; rather they are specifiers in an IP-level structure above the verb phrase. The functional head abstracts on the variable associated with the inflectional ending and creates a predicational relation between the specifier of the functional projection and the expression in its complement. This is illustrated in Figure 2 for the example in (11b) (Quint 3.5.10), using a lexicalist morphology and a bare bones Latin syntax, free of fioritura, in which DP and TP are not projected. The functional heads are not the same thing as the Case heads posited in some theories; the latter are in the noun phrase projection. As already noted for the topic, in a decompositional semantics the inflectional ending might move to the head itself postsyntactically: then the morphological inflection would occupy the syntactic functional head, where it would translate into the semantic operator. (This would be in addition to any role played by the inflectional ending in the lexical layer). Some analyses (particularly in categorial grammar) treat the case ending as a typeraiser: in our analysis it does not raise the type of the specifier of the functional projection but shifts the type of its complement (from $<\mathrm{t}>$ to $<\mathrm{e}, \mathrm{t}\rangle$, by triggering abstraction on a free variable). The morphology is the basis of the variable indexation system; serial order is secondary except in the accusative and infinitive construction and with double accusative verbs. Working bottom up, the 
verb comes with two assumptions, namely that it has an object and that it has a subject; these assumptions are translated as free variables, which correspond to the syntactic traces and saturate the argument positions in the lexical layer. The free variables are carried along by the compositional process and eventually eliminated by lambda abstraction and conversion in their appropriate scopal order: for instance the object is composed before the subject in the neutral order but after it when it is topicalized. The process is quite comparable to what is assumed to happen with quantifier raising, except that the variable is not bound by a quantifier (but by the lambda from the functional head) and inverse scope causes overt raising (scrambling or topicalization). By treating objects like subsidiary subjects, Latin can keep the event description as simple as possible: from a top-down perspective, first the participants are listed and then they are linked to variables in the nuclear event description. This is rather in the spirit of a semantic theory that uses discourse referents like Discourse Representation Theory. In an example like the following

(13) ut... Capuam Romanis eriperent.

(Livy 9.27.2)

so-that Capua-acc Romans-dat take-away

'So that they might seize Capua from the Romans.'

Figure 2. Functional projections for S and DO. Milo Clodium occidit (Quint 3.5.10)

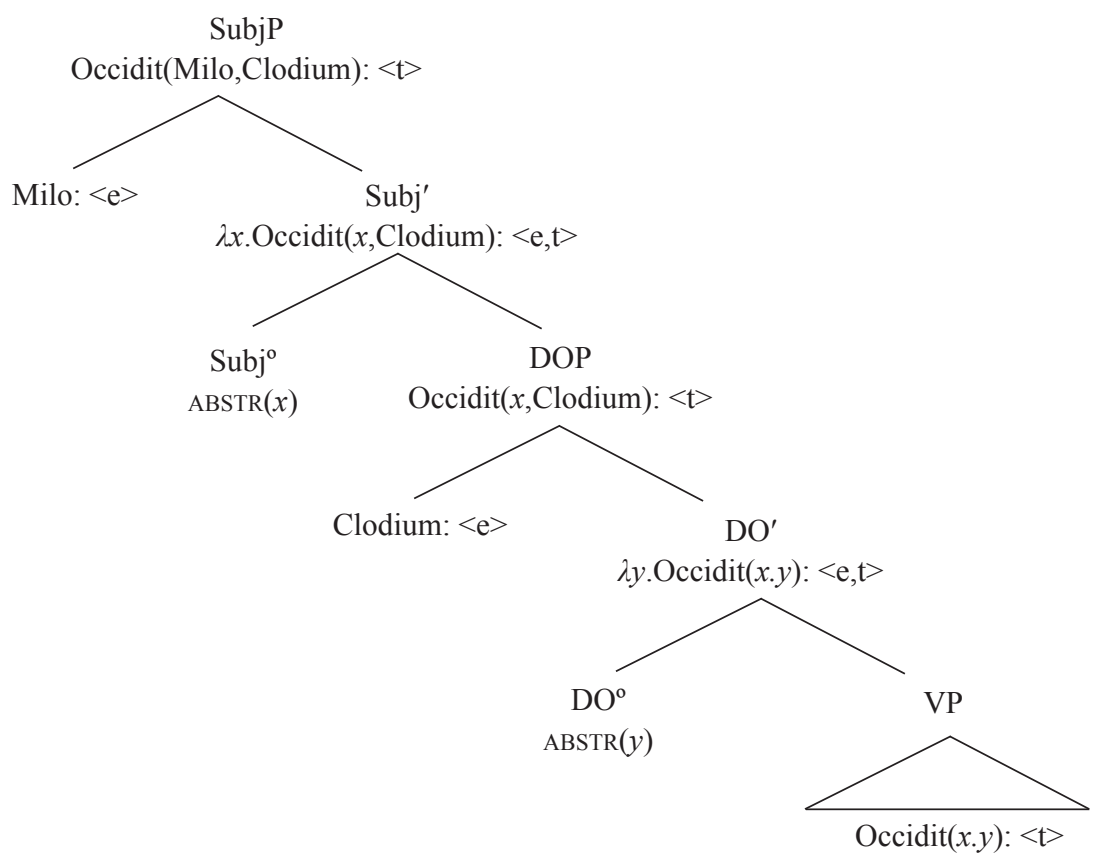


first the discourse referents are established and given descriptive content, then they are picked up by variables in the main formula. Here is a linear version with events: $x y$ z $e \mid \operatorname{Samnites}(x)$, Capuam( $(y)$, Romanis $(z) \mid e$ : Eriperent $(x, y, z)$.

Semantic formulae can quickly become very complicated and it is common practice to abstract away from irrelevant components of meaning to keep the semantics readily intelligible. For instance tense, aspect and plurality are often just ignored. It is also common practice to use property talk rather than event talk (as we have done up to now), although if Rabirius has the property of having killed Saturninus there must have been an event in which he did so. One way of including an event in our semantics is to add a silent event argument to the definition of the verb. So a transitive verb like occido would no longer have the type $<\mathrm{e}$,et $>$ and the translation $\lambda y \lambda x$.Occid- $(x, y)$ but the more complicated type $<\mathrm{e}, \mathrm{e}, \mathrm{ct}>$ and the translation $\lambda y \lambda x \lambda e$.Occid- $(e, x, y)$. In order to enter adjunct information into our semantics for the Latin sentence, we will have to start including such an event argument, because the denotation of an adjunct is a set of events

(14) a. Aequi... arcem Tusculanam... nocte capiunt Aequi-nom citadel-acc Tusculan-acc night-abl capture (Livy 3.23.1)

'The Aequi captured the citadel of Tusculum by night.'

b. Exsules... nocte... arcem occupavere.

exiles-nom night-abl citadel-acc seized

(Livy 3.15.5)

'Some exiles seized the Citadel by night.'

c. nostri... montem gladiis destrictis ascendissent our-nom mountain-acc swords-abl drawn-abl had-climbed (BC 1.47)

'Our men had climbed the mountain with their swords drawn.'

d. C. Cornelius Cethegus... magnum hostium exercitum in C. Cornelius-nom Cethegus-nom large-acc enemy-gen army-acc in agro Sedetano fudit. territory-abl Sedetan-abl routed (Livy 31.49.7)

'C. Cornelius Cethegus routed a large enemy army in the territory of the Sedetani.'

The denotation of nocte is the set of events that took place at night, the denotation of the ablative absolute gladiis destrictis is the set of events that were performed with swords drawn. If we also interpret the clause (or some constituent of it) as a set of events, then adjuncts can be treated as ordinary modifiers. Let's start with the second example (Livy 3.15), in which the adjunct is located to the left of the direct object. Nocte restricts the set of events denoted by the objectverb structure (events of capturing the citadel), throwing out all those events 
that took place during the daytime and leaving only those that occurred at night. This type of restriction amounts to set intersection: by intersecting the set of nocturnal events with the set of citadel-capturing events, we get the set of citadel-capturing events that are nocturnal. In order to do this with our regular compositional mechanism of functional application, we assign the type $<\varepsilon, \mathrm{t}>$ (a set of events, a function from an event to a truth-value) to the set of events of the main clause, and the type $<\varepsilon t, \varepsilon t>$ (a function from a set of events to a set of events) to the adjunct. (Alternatively, the adjunct can be introduced by a functional head of type $<\varepsilon t,<\varepsilon t, \varepsilon t>>$.) The result of functional application is itself a set of events. For instance the set of events in which someone captures the citadel is $\lambda e$.Capiunt( $e, x$, arcem); without going into the details of temporal semantics, the set of events that take place at night (whose run time is a subinterval of the interval occupied by night) is $\lambda e \cdot \operatorname{Nocte}(e)$, which is typeraised to $\lambda P \lambda e . P(e)$ $\wedge \operatorname{Nocte}(e)$. When the latter is applied to the former we get the desired conjunction $\lambda e$.Capiunt $(e, x, \operatorname{arcem}) \wedge \operatorname{Nocte}(e)$. (A less complicated way of doing things is to posit a special compositional rule for modification called predicate modification or more specifically event identification. For this rule we assign the type $<\varepsilon, t>$ to both the adjunct and the main clause; composition just intersects these two sets to give the restricted set of events, again of type $<\varepsilon, t>$. This rule is not suitable if modification is treated as asymmetric). At this point we can apply existential quantification to the set of events: this is effected by an operator $\lambda P[\exists e . P(e)]$ of type $<\varepsilon \mathrm{t}, \mathrm{t}>$, a function from a set of events to a truth value, where $P$ is a variable over sets of events. Finally the subject is entered in the usual way by abstracting over the free subject variable: $\lambda x \exists e$. Capiunt $(e, x$, arcem $) \wedge \operatorname{Nocte}(e)$. For the other examples in (14), which have the object to the left of the adjunct, the object will be abstracted over after composition of the adjunct. Adjuncts can also be clause initial, framesetting adverbials scoping over the whole sentence

(15) proxima nocte... reliquos ex oppido Lucterius educit. next-abl night-abl rest-acc out-of town-abl Lucterius-nom leads-out (cp. BG 8.34)

'The next night Lucterius led the rest out of the town.'

In this case existential quantification over events is delayed until after all the arguments have been saturated; so it applies to $\lambda e$.Proxima-nocte $(e) \wedge$ Educit(e,Lucterius, reliquos, ex-oppido).

Directionals (goals and sources) are mostly arguments, and they are interpreted very closely with the verb. This closeness is actually reflected in English pronunciation: 'fall in the lake' is typically pronounced as one prosodic phrase when the lake is a goal argument ('fall into the lake') and as two prosodic phrases when the lake is a locative adjunct ('fall down while in the lake'); you can insert a slight pause after the verb into the latter much more easily than into the former. In Latin directionals appear closer to the verb than the other arguments 
(16) a. medias vites vinclis in terram defigito.

mid-acc vines-acc fasteners-abl in ground-acc fix

(Cato 41.4)

'Fix the middle of the vines into the ground with fasteners.'

b. arbores pedicino in lapide statuito.

posts-acc bolt-abl in stone-abl set

'Set the posts up in the stone with a bolt.'

(Cato 18.4)

and also than adjuncts, for instance instrumentals

(17) a. Cn. Pompeium ferro domum compulit.

Cn. Pompeius-acc sword-abl home-acc drove

(De Har Resp 58)

'He drove Cn. Pompeius to his house by the sword.'

b. tribunos plebis ferro e rostris expelleret.

tribunes-acc plebs-gen sword-abl from rostra-abl drive

(Pro Sest 84)

'In order to drive the tribunes of the plebs from the Rostra with the sword.'

Preverbal position is the default for directionals; they are not so located only because they tend to have weak focus:

(18) dolium... operculum in dolium indito

jar-acc cover-acc onto jar-acc put

(Cato 104.2)

'Storage jar... put a cover on the storage jar.'

The definite directional (the storage jar) is old information and the indefinite direct object is new information, yet the directional appears to the right of the direct object in broad scope focus. Although directionals can scramble or topicalize
a. ex his locis Cassius cum classe discessit from these-abl places-abl Cassius-nom with fleet-abl departed (BC 3.101)
'Cassius departed from this area with his fleet.'

b. in castra legiones reduxit. into camp-acc legions-acc lead-back

'He led the legions back into camp.'

(BG 4.34)

they are less likely to do so than other noun phrases (the same is true in German) 
(20) a. cisio celeriter ad urbem advectus

carriage-abl quickly to city-acc having-driven

(Phil 2.77)

'Driving quickly to the city in a two-wheeled carriage.'

b. exercitum... clam Alexandriam evocavit army-acc secretly Alexandria-acc summoned

(BC 3.108)

'He summoned the army secretly to Alexandria.'

c. lapidibus optimos viros foro pellis stones-abl best-acc men-acc forum-abl drive

'You drive excellent men from the forum with stones.'

In the first example (Phil 2.77) the instrumental has scrambled to the left of the adverb leaving the goal argument in place, in the second (BC 3.108) the direct object has, in the third (De Har Resp 39) the instrumental adjunct has scrambled but the directional argument stays in its preverbal position. You can say that there was an event involving Antony and Mutina, namely he besieged it, but hardly that there was an event involving Antony and Mutina, namely he went there. The syntax of directionals evidently reflects the fact that they are the argument of the lowest subevent in a decompositional analysis. For instance expelleret (Pro Sest 84 ) in (17b) means 'Cause the tribunes to be driven off the Rostra'; indito (Cato 104.2) in (18) means 'Cause the lid to be put on the jar.' The preposition lexicalizes the resultant state of the verb. The complement of the preposition is not the specifier (subject) of the resultant state subevent but intrinsically part of the predicate. The syntactic evidence indicates that whereas objects raise out of a broad scope focus verb phrase, directionals do not. Take Pompeium... domum compulit (De Har Resp 58) in (17a): the direct object is the argument of the function $\lambda y \lambda e$. Compulit(e,x,y,domum), which already contains the directional.

Crosslinguistically, nonspecific indefinite direct objects can behave differently from ordinary referential direct objects: they tend to be placed closer to the verb than ordinary objects, to resist scrambling, to incorporate easily and to appear as bare nominals without inflection. In Latin, as we have seen, the default position for referential objects is to the left of instrumentals, which in turn are to the left of directionals

(21) a. brachia ferro exolvunt arms-acc sword-abl open

(Tac Ann 15.63)

'They opened the veins of their arms with the sword.'

b. finitimos armis aut metu sub imperium suum coegere neighbours-acc arms-abl or fear-abl under rule-acc their-acc forced (Jug 18.12)

'They brought their neighbours under their rule by arms or fear.'

But nonspecific indefinite and abstract direct objects in fixed phrases with relatively light verbs like impetum facio 'make an attack', gratias ago 'give thanks', 
viam facio 'make way', bellum infero 'wage war on' typically appear next to the verb after instrumentals

(22) a. vi viam faciunt

force-abl way-acc make

'They forced their way forward.'

b. ferro viam facientem sword-abl way-acc making-acc 'Forcing my way with my sword.'

These indefinite objects are not frozen syntactically; they can scramble (which suggests that scrambling is a grammaticalized process)
a. bellum acerrime terra marique gerit war-acc very-fiercely land-abl sea-abl-and wages
(Ad Brut 20.1)
'He is waging war very fiercely by land and sea.'
b. mihi... gratias boni viri agebant (Phil 1.30) me-dat thanks-acc good-nom men-nom were-making 'Good men thanked me.'

but their overall syntactic distribution is quite different from that of referential direct objects. Further evidence of this is their tendency to appear in postverbal position (rarely in Caesar but often in Nepos and Livy), even though they do not represent given information. Semantically they differ in being unindividuated. They do not represent patient or theme participants in the event but rather descriptions of the event itself. Pontem facit (cp. Nepos 1.3.1) could answer the question 'What is he making?' as well as the question 'What is he doing?', but impetum facit (Livy 35.35.18) can only answer the latter question. Facit spells out an outer subevent predicate and impetum is a complement rather than a specifier of the subevent, not the description of a participant in the event but a description of the event itself. We will treat these nonreferential objects as event predicates of type $\langle\varepsilon, t>$ : they compose with the verb by modifying its event argument and creating a sort of compound in which the object of the verb is the event itself. So in this case we actually do want to adjust the type of the verb, making the type and the semantics of light transitive verbs different from that of ordinary transitive verbs. Instead of a type $<\mathrm{e}, \mathrm{e}, \mathrm{ct}>$ with a lambda expression $\lambda y \lambda x \lambda e . \mathrm{V}(e, x, y)$, light verbs require the type $<\varepsilon t, \mathrm{e}, \mathrm{ct}>$ with a lambda expression $\lambda P \lambda x \lambda e . \mathrm{V}(e, x) \wedge P(e)$, where $P$ is the indefinite noun (impetum) and $\mathrm{V}$ is the light verb (facio): $\lambda$ e. $\operatorname{Impetum}(e) \wedge \operatorname{Faciunt}(e, x)$ denotes the set of events that are attacks and are made by $x$. The verb is shifted from a ternary relation between an event and its two participants into a binary relation between an event and its agent, effectively equivalent to the neodavidsonian formula $\operatorname{Agent}(e, x)$, conjoined with a predicate over events $P(e)$. The subject position is saturated by a free variable, which is then abstracted in the usual way when the subject phrase is introduced higher in the tree. The generalization is 
that only arguments which, in one way or another, enter into a complex predicate relation with the verb (directionals and light verb arguments) can occur to the right of adjuncts. This class of arguments is known to be syntactically distinct from other arguments: for instance in Hungarian, which is a discourse configurational language like Latin, bare noun objects and locative complements have their own special word order rules.

\section{Envoi}

We have outlined a syntax-semantics interface for broad scope focus sentences in Latin which conforms with the facts of Latin syntax and uses independently available semantic mechanisms. The compositional system we propose is also suitable for topicalized (and quite possibly scrambled) arguments; so it actually accounts for much of what has been perceived as free argument order in Latin. Our approach is neither purely descriptive and philological (like nongenerative approaches) nor purely formal and theoretical (like the logic-based analyses reviewed above). The former, as we see it, are too extensional: they collect examples without evincing an explanatory theory. The latter risk being too intensional, devising solutions to problems that might be there but actually aren't there (at least, not in Latin). Since neither theory-free philology nor philology-free theory is quite fit for purpose, an interdisciplinary approach that combines philological data with theoretical insight seems more promising. The philological evidence narrows the choice of available syntactic structures, and, in turn, the syntactic structure, together with pragmatic factors, narrows the choice of available semantic frameworks.

\section{References}

Baldridge, Jason. 2002. Lexically Specified Derivational Control in Combinatory Categorial Grammar. PhD dissertation. University of Edinburgh.

Basilico, David. 1998. Object Position and Predication Forms. Natural Language \& Linguistic Theory 16: 541-595. $<$ https://doi.org/10.1023/A:1006042111781>

Beaver, David \& Condoravdi, Cleo. 2007. On the logic of verbal modification. In Aloni, Maria; Dekker, Paul \& Roelofsen, Floris (eds.). Proceedings of the 16th Amsterdam Colloquium, 3-9. Amsterdam: ILLC, University of Amsterdam.

Bowers, John. 2010. Arguments as Relations. Cambridge, Mass: The MIT Press. $<$ https://doi.org/10.7551/mitpress/9780262014311.001.0001>

Casadio, Claudia. 1990. A categorial approach to Latin syntax. Papers on Grammar 3:147-174.

Casadio, Claudia \& Lambek, Jim. 2005. A Computational Algebraic Approach to Latin Grammar. Research on Language and Computation 3:45-60. $<$ https://doi.org/10.1007/s11168-005-1286-0>

Champollion, Lucas. 2015. The interaction of compositional semantics and event semantics. Linguistics and Philosophy 38:31-66. $<$ https://doi.org/10.1007/s10988-014-9162-8> 
Devine, Andrew M. \& Stephens, Laurence D. 2006. Latin Word Order. New York: Oxford University Press.

$<$ https://doi.org/10.1093/acprof:oso/9780195181685.001.0001>

Eckardt, Regine. 2010. A Logic for Easy Linking Semantics. In Aloni, Maria et al. (eds.). Logic, Language and Meaning. Lecture Notes in Computer Science, vol. 6042, 274-283. Berlin \& Heidelberg: Springer.

$<$ https://doi.org/10.1007/978-3-642-14287-1_28>

Fanselow, Gisbert. 2003. Free Constituent Order: A Minimalist Interface Account. Folia Linguistica 37: 191-231.

$<$ https://doi.org/10.1515/flin.2003.37.1-2.191>

Hoffman, Beryl. 1995. Computational Analysis of the Syntax and Interpretation of "Free" Word Order in Turkish. Ph.D. dissertation. University of Pennsylvania.

Jackendoff, Ray. 1990. Semantic Structures. Cambridge, Mass: The MIT Press.

Kracht, Marcus. 1999. Case at the syntax-semantics interface. Unpublished manuscript, II. Mathematisches Institut, Berlin.

Lasnik, Howard. 2001. Subjects, Objects, and the EPP. In Davies, Williams D. \& Dubinsky, Stanley (eds.). Objects and other Subjects, 103-121. Dordrecht: Kluwer. $<$ https://doi.org/10.1007/978-94-010-0991-1>

Ramchand, Gillian C. 2008. Verb Meaning and the Lexicon. Cambridge: Cambridge University Press.

$<$ https://doi.org/10.1017/CBO9780511486319>

Steedman, Mark. 2007. On "the Computation." In Ramchand, Gillian C. \& Charles Reiss (eds.). The Oxford Handbook of Linguistic Interfaces, 575-611. Oxford \& New York: Oxford University Press.

$<$ https://doi.org/10.1093/oxfordhb/9780199247455.001.0001> 